\author{
Karina Pryt \\ https://orcid.org/0000-0002-1925-3695 \\ Institute for Theatre, Film and Media Studies \\ Goethe University in Frankfurt am Main
}

\title{
POLISH-SOVIET WAR IN FILM AND CINEMA: A NEW PERSPECTIVE BASED ON THE FILMS FOR YOU, O POLAND (1920) AND MIRACLE ON THE VISTULA (1921)
}

\begin{abstract}
The Polish-Soviet War, particularly the Battle of Warsaw (13-25 August 1920), soon became a subject of legend and myth. Irrespective of its fundamental political significance, the defeat of the Red Army was glorified as salvation for both Poland and Europe in military, ideological and metaphysical terms. Conducted beyond academia, the narrative was forged mainly by veterans, the Catholic Church and various forms of literature and art. Due to government subsidies, documentary and feature films also conveyed a normative notion of these dramatic events and their participants.

This article focuses on cinematic works like Dla Ciebie, Polsko [For You, o Poland, PL 1920], and Cud nad Wista [The Miracle on the Vistula, PL 1921] produced in order to commemorate the war between the Poles and the Bolsheviks. Taking the iconic turn, this article scrutinises the cinematic self-portrait of the Polish nation that had already been 'imagined' as a bulwark of European culture in the East by earlier literary works. Spotlighting protagonists who were given a place in the pantheon of national heroes, it also asks about those who were denigrated or marginalised like women and Jews. Finally, using quantitative methods and Geographical Information System (QGIS) as a tool, the article juxtaposes the maledominated, ethnically and confessional homogeneous 'imagined nation' with the film entrepreneurs and actual cinema audiences characterised by their diversity.
\end{abstract}

Keywords: Polish-Soviet war, national identity, iconic turn, GIS, Jews, gender, film 


\section{I \\ THE CINEMATIC RESOURCES}

The Polish-Soviet war, especially the manoeuvring battle, better known as the Battle of Warsaw, fought on the outskirts of Warsaw on 13-25 August 1920, quickly became the stuff of legend and myth. Regardless of its actual political significance, the repelling of the Red Army was interpreted as a herculean feat; vital for the survival of both the newly reborn Polish State, and indeed the whole of Europe. That is why it is seen as a milestone with military, ideological and metaphysical dimensions. The myth has continued to be perpetuated by a discourse, removed from the rigours of scholarly oversight, whereas oral and written accounts of the event participants remain central, bolstered by the traditions of the Polish Catholic Church and various forms of literature and art.

The reel also played a part in this process. In the years 1919-21, documentary productions were presented in cinemas, providing reel accounts on the battles for Vilnius and Lviv, the Kiev expedition, and the course of the Polish-Soviet war. The subject of military operations to the East was also prominent in feature films. This series began in 1920 with Bohaterstwo polskiego skauta [The Heroism of a Polish Scout] directed by Ryszard Ordyński and Dla Ciebie, Polsko [For You, o Poland] by Antoni Bednarczyk. A year later, Ryszard Bolesławski made Cud nad Wista [Miracle on the Vistula]; and in 1924 Jan Kucharski made Mitość przez ogien $i$ krew [Love through Fire and Blood]. The topic was also presented in commemorative films made on the tenth anniversary of independence, such as Polonia Restituta by an unknown director, which is a compilation of documentary shots recorded during the battles for independence and the Battle of Warsaw. The same year saw Leonard Buczkowski's debut feature Szaleńcy [The Madmen] and Ryszard Ordyński's documentary Sztandar wolności [Banner of Freedom].

The above-mentioned titles played a special role in creating the legend of the Polish-Soviet war and the shaping of collective imaginations due to their artistic and technical achievements, combining as they did the text's narrative with audio-visual elements, images, scenery, music and acting. Moreover, thanks to the possibilities of reproduction, the films mentioned above would have a greater reach than, for example, theatrical dramas on the same subject and staged at the same time. Indeed, some of the films have survived to this day 
and have been restored thanks to the meticulous restoration efforts by the employees of the National Film Archive - the Audio-visual Institute (FINA) in Warsaw. Stored in FINA's archives, they were made available to a broader audience online as part of the project 'Pamięć filmu. Cud nad Wisłą i inne wydarzenia historyczne w filmowych zasobach FINA' [Film Memory. Miracle on the Vistula and other historical events in the film resources of FINA]. They can also be found on YouTube.

Widely available and watched, they have played their part in the legend and formed the social framework of the memory of the Polish-Soviet war, also featuring in numerous popular and scholarly projects organised in 2020 on the occasion of the centenary of the Polish-Soviet war. This was also the case at the jubilee international conference '1920 in Poland and in Europe/Das Jahr 1920 in Polen und Europa', organised by the Centre for Historical Research of the Polish Academy of Sciences in Berlin thanks to the combined efforts of Iwona Dadej and Igor Kąkolewski. At this conference, perfectly prepared and conducted in pandemic conditions on the internet platform zoom, I had the pleasure of presenting and discussing fragments of two feature films For You, o Poland and Miracle on the Vistula.

\section{II}

METHODOLOGICAL ASSUMPTIONS AND STATE OF CURRENT RESEARCH

This article endeavours to arrive at a broader critical description and a synthetic interpretation of the visual messages contained in the versions available on YouTube. ${ }^{1}$ It should be emphasised here that both films have been preserved only in fragments, but thanks to the efforts of FINA, they were provided with background music, which in the era of silent cinema was of great importance when it came to the reception of cinematic work. However, the analysis of all the films remains as impossible as it is to recover the atmosphere of the cinema in the early 1920s. Watching films from that era in front of a computer screen does not reflect the cinematographic experience of viewers watching films with live musical accompaniment. For You, o Poland

${ }^{1}$ Dla ciebie Polsko, https://www.youtube.com/watch?v=ViOZBiEnjyU; Cud nad Wista, https://www.youtube.com/watch?v=I_23gujc6Ik [Accessed: 9 Nov. 2021]. 
premiered on 25 September 1920, in a cinema space located in the 1700-seat hall of the Warsaw Philharmonic. Out of the thirty cinemas operating in the capital at that time, the Philharmonic offered the best acoustics and the best orchestra. Miracle on the Vistula premiered on 16 March 1921, in the Palace Cinema, which had 1,200 seats and also enjoyed fine acoustics. For today's cinema-viewers, the Polish-Soviet war belongs firmly in the past; however, for cinemagoers in 1920 and 1921, this was an unfolding conflict in touching distance of their lives.

Each reception of a film is individual, and the readings of visual messages are often undertaken from a specific point of view and in correlation with a scholar's competences, experiences and research tools. In this article, I propose an interdisciplinary approach based on a wealth of literature from various fields. The basic findings are contained in the synthetic views of Polish film history, edited by Jerzy Toeplitz, ${ }^{2}$ and the outline of the economic history of the Polish film industry by Edward Zajiček. ${ }^{3}$ More information is provided by Małgorzata Hendrykowska's monograph on documentary films, ${ }^{4}$ and works devoted to historical feature films of a patriotic nature by Tadeusz Lubelski ${ }^{5}$ and Grażyna Stachówna. ${ }^{6}$

As emphasised by the researchers mentioned above, the Polish film industry, which until 1939 operated essentially on a free-market basis, produced historical films at the request of the state authorities. The relevant directives were issued by the Ministry of Culture and Art, and until 1922 also by the Propaganda Department of the Presidium of the Council of Ministers, and the Central Film Office established in 1919 at the Command-in-Chief of the Polish Army, which had emerged from the Film Office at the Polish Legions, established two years earlier. Films produced with the financial support of these institutions usually depicted the patriotic aspirations of Poles in the former territory of the

${ }^{2}$ Jerzy Toeplitz, Historia filmu polskiego (Warszawa, 1966-1974).

${ }^{3}$ Edward Zajiček, Zarys historii gospodarczej kinematografii polskiej (Łódź, 2015²).

${ }^{4}$ Małgorzata Hendrykowska, Historia polskiego filmu dokumentalnego (1896-1944) (Poznań, 2014).

5 Tadeusz Lubelski, Historia kina polskiego. Twórcy, filmy, konteksty (Katowice, 2009); Tadeusz Lubelski and Maciej Stroiński (eds), Kino polskie jako kino narodowe (Kraków, 2009), 35-56.

${ }^{6}$ Grażyna Stachówna, 'Ułan, dziewczyna (i koń)', in Lubelski and Stroiński (eds), Kino polskie. 
Russian partition. In the early 1920s, the most common motif was the First World War and events related to the Polish-Soviet war. In the 1930s, a popular topic was the Revolution of 1905-7. By allocating subsidies and offering tax reliefs, these authorities also influenced these films' content and ideological message.

For this reason, I do not treat For You, o Poland and Miracle on the Vistula as original works of authorship but regard them as being both part of the mobilisation campaign and commemorations of the battles themselves. When analysing both films, I also draw on theoretical and methodological considerations resulting from the iconic turn in historical research, as led by scholars such as Dorota Skotarczak ${ }^{7}$ and Piotr Witek. ${ }^{8}$ An important point of reference are the reflections on the nature of historical films undertaken by Piotr Witek, ${ }^{9}$ Piotr Skrzypczak, ${ }^{10}$ Maciej Białous, ${ }^{11}$ and Monika Piotrowska, ${ }^{12}$ as well as collected articles edited by Mariusz Guzek and Piotr Zwierzchowski, ${ }^{13}$ or by Iwona Kurz. ${ }^{14}$

From a historiographical perspective, these films are interesting both as historical sources and in terms of their popularisation of history. As historical sources, they show material culture, actors' performance and reveal the cultural and social contexts. As vehicles of historical knowledge, they undoubtedly have a wider range of influence than historiographical works, as they are easier to perceive and have a strong influence on the senses and emotions. In both functions, films do not present events and the world as they were, but construct a cultural

${ }^{7}$ Dorota Skotarczak, Historia wizualna (Poznań, 2012).

${ }^{8}$ Piotr Witek, 'Metodologiczne problemy historii wizualnej', Res Historica, 37 (2014), 159-76.

9 Piotr Witek, 'Metafora źródła czyli film w funkcji poznawczej', Przegląd Humanistyczny, xlvi, 1 (2002), 57-70.

${ }^{10}$ Piotr Skrzypczak, 'Nowe źródło historii? Redefinicja gatunku filmu historycznego w dzisiejszym kinie polskim', Media - Kultura - Komunikacja Społeczna, xiii, 3 (2020), 29-53.

${ }^{11}$ Maciej Białous, Społeczna konstrukcja filmów historycznych. Pamięć zbiorowa i polityka pamięci w kinematografii polskiej lat 1920-2010 (Białystok, 2015).

${ }^{12}$ Monika Piotrowska, 'Rola i znaczenie filmu w popularyzacji historii a kształtowanie społecznej świadomości historycznej’, Zeszyty Naukowe Towarzystwa Doktorantów UJ Nauki Humanistyczne, 14 (2016), 59-78.

${ }^{13}$ Mariusz Guzek and Piotr Zwierzchowski (eds), 1918 - kino polskie wobec odzyskania niepodlegtości (Bydgoszcz, 2020).

${ }^{14}$ Iwona Kurz (ed.), Film i historia: Antologia (Warszawa, 2008). 
reality using the mechanisms of appropriation and exclusion. At the same time, being collective works, as Witek claims, films are created and function in a specific social group, also known as the communication community within which they were produced. ${ }^{15}$ Therefore, as Piotrowska writes, "the creators not only present historical episodes of cultural reality, but also co-create the same by way of an interaction with the recipient, using symbols and metaphors whose language can be understood by a given community". ${ }^{16}$

Analysing the construction of cultural reality in the films For You, o Poland and Miracle on the Vistula, I also ask a question about the communicational community of Polish cinematography. Here I am referring to the constructivist concept of the nation as represented, among others, by Benedict Anderson ${ }^{17}$ and Karl Deutsch. ${ }^{18}$ Following Anderson, I assume that nations arose thanks to the mass media as "imagined communities". Whereas following Deutsch, I perceive the nation as a communicative community in a similar sense. ${ }^{19}$

Taking the constructivist approach, I treat the discussed films as elements of social discourse shaping and organising areas of knowledge about the nation. The national discourse, which essentially emerged in Europe in the nineteenth century, is based on the premise that modern societies pursue the distant goal of a homogeneous nation-state. Thus, this narrative takes over the inclusive and exclusive practices of the national movement and marks dichotomous boundaries between what is foreign and what is native. At the same time, differences and inconsistencies are eliminated, and therefore they have been rendered meaningless. ${ }^{20}$

Searching for elements recognised as native and foreign in the national stories about the Polish-Soviet war in the films For You, o Poland and Miracle on the Vistula, I also make recourse to analyses of various

${ }^{15}$ Witek, 'Metafora źródła', 57-70.

${ }^{16}$ Piotrowska, 'Rola i znaczenie filmu', 59-78.

${ }^{17}$ Benedict Richard O'Gorman Anderson, Imagined Communities: Reflections on the Origin and Spread of Nationalism (London, 1991).

${ }^{18}$ Karl Wolfgang Deutsch, Nationalism and Social Communication. An Inquiry into the Foundations of Nationality (Cambridge, MA, 1966).

${ }^{19} \mathrm{Ibid}$.

${ }^{20}$ Sebastian Conrad, Shalini Randeria, and Beate Sutterlüty (eds), Jenseits des Eurozentrismus: Postkoloniale Perspektiven in den Geschichts- und Kulturwissenschaften (Frankfurt am Main-New York, 2002). 
literary genres carried out by Dobrochna Ratajczakowa, ${ }^{21}$ Maria Janion $^{22}$ and Ewa Pogonowska. ${ }^{23}$ In tracking the practices of exclusion, I refer to the work of representatives of Jewish studies, such as Natan Gross, ${ }^{24}$ Marcos Silber, ${ }^{25}$ Zofia Borzymińska and Rafał Żebrowski, ${ }^{26}$ and research on anti-Semitism undertaken by the historian Agnieszka Pufelska. ${ }^{27}$ Fresh impulses about gender roles in Polish national discourse are also provided by feminist criticism as per the works of researchers Agnieszka Graff ${ }^{28}$ and Elżbieta Durys. ${ }^{29}$

Here, I juxtapose the attribution of cultural reality in the films For You, o Poland and Miracle on the Vistula against the communication community in Polish cinematography, which was very diverse in terms of language, culture and nationality. It should be emphasised here that none of the film studios had their own cinema network guaranteeing the full exploitation of the films and the recovery of costs through box-office takings. In this weave of dependencies, it is worth paying attention to the presence of national minorities. Polish Jews played

${ }^{21}$ Dobrochna Ratajczakowa, 'Cud nad Wista. Obrazy wojny polsko-sowieckiej 1920 roku w dramacie popularnym lat dwudziestych', Roczniki Humanistyczne, xlii, 1 (1994), 123-36.

${ }_{22}$ Maria Janion, 'Polska w Europie', Nauka, 1 (2004), 7-30; ead., Niesamowita stowiańszczyzna: Fantazmaty literatury (Kraków, 2006).

${ }^{23}$ Ewa Pogonowska, Dzikie biesy: Wizja Rosji sowieckiej $w$ antybolszewickiej poezji polskiej lat 1917-1932 (Lublin, 2002).

${ }^{24}$ Natan Gross, Film żydowski w Polsce (Kraków, 2002).

${ }^{25}$ Marcos Silber, 'Narrowing the Borderland's Third Space: Yiddish Cinema in Poland in the Late 1930s', Simon Dubnow Institute Yearbook, 7 (2008), 229-51.

${ }^{26}$ Zofia Borzymińska and Rafał Żebrowski, 'Żydowskie ulice w Warszawie', file:///D:/E-Literatur/ZB_RZ_Z_ydowskie_ulice_Warszawy.pdf.

${ }^{27}$ Agnieszka Pufelska, 'Moc obrazów obcego - Stereotyp Żyda w Polsce i Niemczech', http://www.polska-niemcy-interakcje.pl/articles/show/48; ead., 'Stabile Feindbilder gegen die instabile Zeit Der jüdische Bolschewismus als Propagandainstrument in der Weimarer Republik', in Jörg Ganzenmüller, Gerd Koenen, Bernhard H. Bayerlein, Eva Oberloskamp, Karsten Brüggemann, Agnieszka Pufelska, Thomas Kroll, Hans Woller, and Julia Richers (eds), Verheißung und Bedrohung: Die Oktoberrevolution als globales Ereignis (Göttingen, 2019).

${ }^{28}$ Agnieszka Graff, 'Płeć i naród tu i teraz. Kilka uwag o genderowym i seksualnym wymiarze współczesnego polskiego nacjonalizmu', in Elżbieta H. Oleksy (ed.), Tożsamość $i$ obywatelstwo w spoteczeństwie wielokulturowym (Warszawa, 2008), 140-58.

${ }^{29}$ Elżbieta Durys, 'Joanna i Róża - subwersywny wymiar macierzyństwa a filmy pamięci narodowej', in Patrycja Chudzicka-Dudzik and Elżbieta Durys (eds), Konteksty feministyczne. Gender w życiu społecznym i kulturze (Łódź, 2014), 235-52. 
a central role among producers, distributors and cinema owners - as emphasised by Gross, Silber and others - being politically, socially, culturally and linguistically diverse. In the case under study, the production side for For You, o Poland was admittedly predominantly Christian shareholders from Polfilma, ${ }^{30}$ whereas Orientfilm ${ }^{31}$ was responsible for Miracle on the Vistula. However, Jewish cinema owners or managers were also involved in the commercial dissemination of these films. As previously assumed, due to the interdependence in the Polish film industry, there was no room for anti-Semitism, and no anti-Semitic film was made in Warsaw. ${ }^{32}$ However, this belief should be revised, as I will present on the example of both productions.

When considering the interdependence of Polish cinematography, it is impossible to neglect the cinema audience, which was even more diverse than the film industry. While men dominated the cinematographic companies, there were also women to be found in the audiences. In Polish film studies, however, there has been no independent research on the participation of women in cinematographic performances in Poland in the interwar period. The participation of national minorities in Polish cinematographic culture was noted by researchers dealing with the regional history of cinema such as Małgorzata Hendrykowska and Marek Hendrykowski, ${ }^{33}$ Urszula Biel, ${ }^{34}$ Mariusz Guzek, ${ }^{35}$ Barbara Gierszewska, ${ }^{36}$ Łukasz Biskupski, ${ }^{37}$ and Paweł Sitkiewicz, ${ }^{38}$ who has analysed the habit of cinema-going, remains to be thoroughly researched. Much of this research has focused mainly on Polish-language sources and only sporadically referred to local

30 'Obwieszczenie', Obwieszczenia Publiczne. Dodatek do Dziennika Urzędowego Ministerstwa Sprawiedliwości (12 Oct. 1918), 8.

31 'Polsko-amerykańskie wydawnictwo filmowe Orientfilm', Kalendarz: Czerwony Krzyż Organ Polskiego Towarzystwa Czerwonego, 21-24 (1922), 153.

32 Gross, Film żydowski.

${ }^{33}$ Małgorzata Hendrykowska and Marek Hendrykowski, Film w Poznaniu i Wielkopolsce: 1896-1996 (Poznań, 1996).

${ }^{34}$ Urszula Biel, Śląskie kina między wojnami, czyli przyjemność upolityczniona (Katowice, 2002).

${ }^{35}$ Mariusz Guzek, Filmowa Bydgoszcz, 1896-1939 (Toruń, 2004).

${ }^{36}$ Barbara Gierszewska, Kino i film we Lwowie do 1939 roku (Kielce, 2006).

${ }^{37}$ Łukasz Biskupski, Miasto atrakcji: Narodziny kultury masowej na przełomie XIX i XX wieku kino $w$ systemie rozrywkowym Łodzi (Warszawa, 2013).

${ }^{38}$ Paweł Sitkiewicz, Gorączka filmowa. Kinomania $w$ międzywojennej Polsce (Gdańsk, 2019). 
newspapers published in other languages. Few film scholars refer to Jewish newspapers published in Polish, while the exploitation of sources written in Yiddish remains the exclusive domain of Jewish studies.

Ela Bauer, possessing the appropriate linguistic competences, made a scholarly analysis of the Yiddish press from the 1920s, and concluded that "in some places, such as small towns on the periphery, Jews constituted the majority of movie-viewers". ${ }^{39}$ Bauer so maintains: "In almost all cities and small towns movies were considered Jewish entertainment. Movie theatre owners and film producers relied on Jewish customers to fill the halls". ${ }^{40}$

Bauer's thesis seems too audacious, but it gives rise to new considerations on the source base and methodology of research on cinemagoers and the reception of films in interwar Poland. A quantitative analysis of the correlation between the topography of cinemas and the distribution of national minorities is needed. It should be emphasised that at the beginning of the 1920s cinema was a purely urban phenomenon, and cities and towns had a very diverse national composition. Much of the 700 cinemas in operation at the time were located in urbanised areas in the west of the country, where the German population was strongly represented. Conversely, Ukrainians and Lithuanians attended cinemas in the eastern territories. Jewish cinema aficionados could have made up the majority of viewers in the towns of central and eastern Poland. However, the same cannot be said about cities such as Warsaw, Łódź, Cracow or Lviv, where the Jewish population comprised about a third of the inhabitants.

The use of quantitative methods, currently experiencing a real boom along with the digital revolution, allow for the systematisation and specification of data on historical demography and the economic history of Polish cinematography. In this article, I propose using spatial analysis using the QGIS program ("Quantum GIS") on the example of Warsaw. The possibilities of using Geospatial Information Systems (GIS) in mapping cinematographic culture were first presented by Jeffrey Klentonic. ${ }^{41}$

${ }^{39}$ Ela Bauer, 'The Jews and the Silver Screen: Poland at the End of the 1920s', Journal of Modern Jewish Studies, xvi, 1 (2017), 80-99 (here 87).

${ }^{40}$ Ibid.

${ }^{41}$ Jeffrey Klenotic, 'Putting Cinema History on the Map: Using GIS to Explore the Spatiality of Cinema', in Richard Maltby, Daniël Biltereyst, and Philippe Meers (eds), 


\section{III}

\section{CRITICAL DEPICTIONS AND A SYNTHETIC ANALYSIS OF THE FILMS FOR YOU, O POLAND AND MIRACLE ON THE VISTULA}

The image of the Polish-Soviet War in For You, o Poland and The Miracle on the Vistula is part of the Polish national discourse taking up the historical experiences of Poles in the eastern territories of the country in the former Russian partition. The event itself suggested a repetition of history, prompted the duplication of old patterns and the renewal of myths and topoi developed in earlier texts of culture. Their identification is difficult in the case of For You, o Poland, due to the poor quality of the reel. They can be recognised much more clearly in the more elaborate Miracle on the Vistula, whose impressive set design was the joint work of Ewelina Libratowicz-Mucharska, Wacław Borowski and Józef Galewski.

Basically, both films refer to an earlier social and philosophical thought that had created the image of Poland as an antemurale christianitatis, positioning Christian Poland of the Roman Catholic rite as the last bastion of European culture, in opposition to Orthodox Russia and in opposition to the followers of other religions living in the eastern territories. These films thus reproduce the myth of the Catholic Poles, which had its origins in the upheavals of the seventeenth century and were honed by the political contexts of the partitions. Taking up the subject of the Polish-Soviet War, the films also fit into the romantic tradition of Polish irredentism, especially evocative of the patriotic uprisings against tsarist Russia. We can also find references to Positivist thought, which espoused work ethic and ideas as a way of regaining independence.

At the same time, the films drew on the prototypes of Polish art and national literature, which popularised these ideas. Particularly noticeable are the numerous references to the national poet Adam Mickiewicz's work Pan Tadeusz (published in 1834), whose historical background is the Napoleonic campaign of 1812. In addition, the films refer to the novel by Eliza Orzeszkowa Nad Niemnem [On the Niemen]

Explorations in New Cinema History: Approaches and Case Studies (Malden MA, 2011), 58-84. I am indebted to his inspirational and methodical guidance. I gained practical skills during a week-long training at my university and then under the supervision of Tomasz Panecki, the current head of the Department of Historical Atlas of the Institute of History of the Polish Academy of Sciences in Warsaw. 
from 1888, which explores the vistas and strata of Polish society, referring to the times of the January Uprising (1863). Moreover, Miracle on the Vistula evokes Stanisław Wyspiański's drama Wesele [The Wedding] from 1901, which deals with the subject of wasted opportunities in terms of the achievement of independence. The films are all the more in-depth for their extratextual presence of these historical layers.

The plots of both films are built on historical and private spheres. Assuming both chronicle and historiographic functions, both films present the political context with cross-section captions, thus suggesting the authenticity of the account and introducing the viewer to the role of an eyewitness of the events being presented. For You, o Poland starts with the caption: "After the withdrawal of the German army from Vilnius, fierce battles ensued for control of the city. In December 1918, the communists captured Vilnius. From the beginning of 1919, there were battles between the Polish army and the Bolsheviks". The following caption continues: "On 16 April 1919, the offensive against Vilnius began. On 19 April 1919, Polish units entered the city. For two more days in the suburbs, battles with the Bolsheviks continued. The film tells about the events of April 1919". Here it should be added that the last episode takes place in August 1919, which was probably the first ending of the film. The currently available version ends with documentary photos showing Józef Piłsudski's triumphant entry into Warsaw.

Shown in two parts, Miracle on the Vistula represented a continuation of the story from For You, o Poland. The action of the first part begins in the winter of 1919, while the climax of the second part is the decisive battle of August 1920. The first inter-section caption introduces the historical context, dating the loss of independence approximately from the first partition of Poland: "The captivity, tearing and suffering of Poland lasted 150 years. The storm of war smote the oppressors. The Polish Eagle triumphantly spread its wings again, the country was awoken to life and work, and the Polish soldier fought for his homeland". The threat for regained independence is personified by the communist agitator Jan Rudy (Stefan Jaracz), featured at the beginning of the film.

Just like For You, o Poland, Miracle on the Vistula ends with documentary shots, confirming the account's authenticity. The ceremonial handing over of the sceptre to Marshal Józef Piłsudski in Warsaw on 14 November 1920, in the presence of dignitaries of the Catholic 
Church and important public figures, was recorded on the footage. In addition, the final scenes emphasise the role of commemoration by the insertion of photos of the wreath-laying at the monument dedicated to the Fallen for the Homeland, which had been unveiled on All Souls' Day the same month, at the junction of then Aleja 3 Maja (today Aleje Jerozolimskie) and Nowy Swiat. The last frame featured a monument, which no longer exists, showing a sarcophagus with the sign of the cross and a crowned eagle, symbolising the collective resting place of those who gave their lives for their country. ${ }^{42}$

When looking for an answer to the question of whom exactly both films pay tribute to, I will start by determining the locations of the action. In both films, these are mainly the eastern regions affected by the fighting, commonly referred to as the eastern borderlands [kresy], which in these films are shown to be inhabited exclusively by the Polish ethnic Catholic population. There is an absence of Christians of other denominations, there are no followers of Islam, and we do not see any Jewish towns, shtetls, characteristic of central and eastern Polish lands.

Referring to the prototypes of national literature, the main elements of the world depicted are the borderland gentry manors and the peasant villages, which symbolise the Polish homeland. Their inhabitants, i.e. the nobility and peasants, are linked with each other by their place of residence, agrarian tradition, religion and the same uniform threat. There is no room for social conflicts in the fatherland outlined in this way that could justify the communist ideology. On the contrary, the representatives of both states live in remarkable agreement with each other, accepting the social hierarchy and their economic differences.

In For You, o Poland, these are the inhabitants of the village of Okrzyniec in the Vilnius Region, including Franek (Henryk Rydzewski), his beloved Hanka (Jadwiga Doliwa) and her grandfather Wojciech Siekiera (Stanisław Jasieński). Living in the countryside as peasants, these three characters may also belong to the impoverished parochial nobility, which is portrayed in Nad Niemnem on the example of the Bohatyrowicz family. Hanka and her grandfather devote themselves to the everyday activities on the farm, thus signalling the hidden meaning of positivist patriotism in terms of work. The reel captured priceless mementoes of material culture, such as a modest but tidy

${ }^{42}$ https://muzeumwarszawy.pl/bitwawarszawska/. 
farmyard and the interior of a peasant hut with religious paintings on the walls and simple tableware on the table. Referring to the national epic Pan Tadeusz, one of the scenes shows Hanka, who, like Zosia, is to be seen giving millet to hens. In Okrzyniec, the wealthy nobility is represented by the figure of the nobleman Marcin Oksza (Antoni Różański), a distinguished participant in the January Uprising of 1863.

In Miracle on the Vistula, the families and relatives of the nobleman Granowski (Wincenty Rapacki) and the peasant Maciej Wierun (Edmund Gasiński) become close to each other. The dignified role of a symbolic and mythical Polish mother [matka Polka] is played by Lady Granowska (Honorata Leszczyńska), who is responsible for raising her two sons in the spirit of patriotism and adherence to the Catholic faith. Her younger son, Wojtuś, is also studying in Warsaw, which indicates the geographical and ideological connection of the Granowski manor house with the capital of the reborn Polish state. Her adult son, Jerzy (Jerzy Leszczyński), in reference to Wyspiański’s drama, The Wedding, remains on a friendly footing with Wierun's son Michaf (Bogusław Samborski), and his daughter Krysta (Jadwiga Smosarska), who loves him. In the background, there are also representatives of the Polish intelligentsia, Dr Jan Powada (Władysław Grabowski) and Ewa (Anna Belina), a laboratory technician employed in the hospital he runs, who spend much of their free time at the Granowski estate, partaking of its idyllic atmosphere.

Drawing on literary prototypes, both films stylise the noble manor house as the cradle of the Polish character. Reproducing topoi that were discernible at the end of the eighteenth century, the estates of the insurgent Oksza and the Granowski family are presented as a reservoir of memory about the shared past, a refuge of the most beautiful Polish customs and traditions. The film contains mementoes of material culture, such as the nobility's costumes and the manor's interior, to include vibrant decor, relics, paintings, furniture, and tableware. Large manor houses convey the image of the Polish idyll in the borderlands. As at Soplicowo (Pan Tadeusz), in the Granowski manor house, the Polish noble tradition is cultivated, expressed by a specific etiquette for shared meals and regulated customs and activities appropriate to age, gender and position.

Cultivating the old traditional national values, the inhabitants spend most of their time at the manor house, passing the day in conversation and partaking of pleasant walks, enjoying the beauty 
of nature. Granowska deals with needlework, and her husband rests in front of Piłsudski's portrait, whom he resembles, signalling an ideological closeness. Miracle on the Vistula also refers to the iconographic scene from the feeding of domestic birds from Pan Tadeusz, recalling it in a comic function. Here, not a female figure, but the nobleman Granowski gives millet to the hens.

The most beautiful scenes undoubtedly depict preparations for Christmas in 1919 in both the Granowski manor house and the Wierun cottage, indicating a commonality among nobility and the peasants. The bond between both states was also expressed by the visit of Maciej and Krysta with the Christmas nativity scene at the Granowski manor house, the exchanging of gifts, and collective mirth and merriment. From the inter-section captions, we also learn that Krysta, as a half-orphan, was reared within the bosom of the Granowski family, thus acquiring good manners and etiquette and a love of fine arts. While Zosia of Pan Tadeusz, after her mother's death, grew up under the watchful eye of Telimena and devoted herself to household chores, Krysta devotes herself to handicrafts and sculpting at Granowski manor.

The invasion of the Bolsheviks poses an existential threat to this idealised world and the represented social order. The Bolsheviks and the possibilities of overcoming them were presented in both films using similar schemes and editing procedures. For You, o Poland visualises the atrocities of the Bolsheviks, alternating with photos of Polish soldiers winning battles in various places on the front. In Miracle on the Vistula, the crimes of the Bolsheviks are presented alternately with the scenes of Lady Granowska and her son Wojtuś praying.

The soldiers of the Red Army are portrayed in both films as a military, ideological and metaphysical threat, based on an earlier stereotype of the other, described in literary examples by Maria Janion and Ewa Poganowska. The characterisation of the Bolsheviks strengthens the hostility towards the Russians, which had been well-established during the partitions. The stereotyping of Russians is also part of the discourse on the Orientalisation of Russia and its inhabitants. Its core is binary opposition. Europe is culture and civilisation, and Russia denotes an absence of culture, anti-civilisation. The Russians, pushed beyond the circle of European culture, are enemies of Christianity of the Roman Catholic rite, which is safeguarded by Poland. As religious and cultural aliens, Russians belong to the anti-Christian, wild and 
Asian East. In line with this pattern, in both films the culturally superior Catholic Poles and Europeans struggle with the brutal, feral and ruthless hordes of Bolsheviks.

At the same time, the characterisation of the Bolsheviks is in the framework of the anti-Judaism (that is, a legacy of Christianity) and the modern anti-Semitism that derives from it. To paraphrase the words of the historian Agnieszka Pufelska, it is worth recalling here that the basis of the anti-Judaism was the early Christian dogmatism assuming that God had turned his back on the nation of Israel with the destruction of Jerusalem and its Temple in $70 \mathrm{AD}$ following the Jews' rejection of God and their crucifixion of the Messiah. The axioms of anti-Judaism were the basis of modern anti-Semitism and its component of the conspiratorial theory of history, assuming that globally and omnipotently organised Jews want to take over the world. Then they were taken over to the concept of 'Judeo-Communism' [żydokomuna], according to which communism, conceived by a Jew, Karl Marx, was to be, next to capitalism, another instrument in the hands of Jews aimed at annihilating Christian civilisation. ${ }^{43}$

The depiction of the Bolsheviks in both films to varying degrees and at different levels evokes the tradition of the Antichrist and the identification of communists and Jews. In For You, o Poland, we meet the Bolsheviks at the very beginning of the film, when they come to the hometown of Franek and Hanka. The captions emphasise the drama of the situation: "The Bolsheviks are murdering the inhabitants and plundering the village". The scenes show how the invaders humiliate and terrorise defenceless civilians and prepare to rape powerless, barefoot and fearful women. These scenes are contrasted with the strength of the Polish army unit that comes to their aid. Another caption informs, however, that not everywhere ended so happily: "The rape and torture perpetrated by the Bolshevik hordes did not spare even children and the elderly". What may threaten the whole of Poland is presented by the incursion against Marcin Oksza's manor house and property. Celebrating the occupation of the manor, the Bolsheviks get drunk, shoot at paintings on the walls, and destroy the material culture of the manor, including the precious mementoes linking the present with the past. They savour the prospect of raping the women who have been brought to the Oksza estate for this purpose.

${ }^{43}$ Pufelska, 'Moc obrazów obcego'. 
Bolshevism is personified in particular by the figure of the unit commander (Ryszard Sobiszewski), who comes to the fore both in the scenes taking place in the village of Hanka and Franek, as well as in the manor of Marcin Oksza. In the intersection caption, he is presented as "Bolshevik Sasha who was distinguished by his particular cruelty". He also tries to rape women in the village and in the manor house. Film historian, Tadeusz Lubelski, mentions this character in his description of the Bolsheviks: "Their wildness and cruelty are visible at first glance: in addition, the unit commander has clearly Jewish features". ${ }^{4}$

Paraphrasing Pufelska again, it should be emphasised that ascribing some aspects of appearance or character traits to Jews derives from images preserved to this day, taken from anti-Semitic fantasies. The idea of a specific Jewish appearance was reinforced as anti-Judaism evolved into modern racist anti-Semitism. The differences between Jews and non-Jews, previously defined according to religious criteria, were mainly located within the body and assumed to be unchangeable. ${ }^{45}$

The depiction of the Bolshevik Sasha evokes associations with anti-Semitic caricatures, which epitome the projection of this stereotyping. Indeed, Sasha, shown many times in close-ups, resembles the iconographic caricatures of Lev D. Bronstein-Trotsky. As Pufelska writes, Trotsky "was and is considered a symbol of the revolutionary movement not because he was one of the leading Bolshevik leaders, but because he was a Jew". ${ }^{46}$ His character was used in the government mobilisation campaign to fight the Red Army. The diabolical image of Trotsky reproduced on a large scale in Poland and abroad at the time, clearly alluded to the conspiracy theory of 'Jewish communism'. A Bolshevik with a Russian name, Sasha, personifies communism as a demonic tool in the hands of Jews who want power over the world. By driving the Bolsheviks from both the village and the manor of Marcin Oksza, Polish cavalry units not only achieved a military victory but also defended their homeland against metaphysical destruction.

Referring to the legend of divine intervention in repelling the Bolsheviks, Miracle on the Vistula clearly exposes the metaphysical dimension in the depiction of the Bolsheviks, juxtaposing their views

${ }^{44}$ Lubelski, Historia kina polskiego, 47.

45 Pufelska, 'Moc obrazów obcego'.

${ }^{46}$ Ead., 'Stabile Feindbilder'. 
with Poles praying to Jesus Christ. Essentially, the movie presents a more varied picture of the threat by introducing several types of Bolsheviks. The first of them is the aforementioned communist agitator Jan Rudy, who appears three times. As a dark, mysterious figure, he hands out leaflets with a communist message at the film's beginning. Then he comes to a country inn to persuade Polish peasants to change loyalties and join the Bolshevik side. The last time he appears to one of the peasants as a soulless and mocking demon whom he had previously believed and, succumbing to his suggestions, fought in the ranks of the Red Army.

Bolshevism is also personified by the military units attacking the Polish field hospital. As part of the discourse on the oriental aspect of Russia, the Red Army soldiers were shown as eastern, being therefore different from the European civilisation. Some of them evoke associations with Tatar warriors. One close-up demonstrates the gloomy figure of a Bolshevik with a long beard, which can be read as a reference to the traditional appearance of Orthodox Jews and the figure of the Antichrist. This trail is clearly indicated by following sequences that show the fervently praying residents of the manor, especially Granowska and her son Wojtuś, and the shot of the crucified Jesus Christ. The next frame shows the modern type of Bolshevik in the form of a beardless man wearing a leather jacket, and smoking. The juxtaposition of these approaches suggests that communism as a modern ideology is related to, or even derived from, an earlier image of Jews as the followers of the Antichrist.

The stereotypical connection between communism and the Jews is undermined in this film by the figure of Szmul Wodociag (Henryk Małkowski), a comedian of the Polish acting troupe. Itinerant actors, introduced in the background as retardation, introduce comic elements, ease tension and entertain the audience. Wandering through the borderlands, they belong to the Polish cultural circle, but they represent a much lower personal culture than the manor inhabitants. Unlike the gloomy, sinister, demonic Bolshevik with a long beard, the comedian with a funny Polonised name, Wodociąg [Waterworks], represents a comic, homely Polish Jew. Nevertheless, Wodociąg, like his other wandering companions, is not a fully-fledged participant in the events. While fleeing the Bolsheviks, the actors only accidentally participate in one of the armed skirmishes, and then - in a comic function - they claim their undeserved participation in the victory. 
The character of Wodociag at the same time trivialises the participation of Jewish soldiers in the Polish army, a participation that is left unmentioned in For You, o Poland. The Miracle on the Vistula also omits the subject of the Jabłonna camp, where 17,000 Jews were interned on 16 August 1920, including professional soldiers and officers. All of them had been withdrawn from the front. ${ }^{47}$ The camp, established on the confidential order of the Minister of Military Affairs, General Kazimierz Sosnkowski, and closed after 25 days, was a sign of the authorities' distrust of Polish Jews. Thus, Polish Jews were denied the right to a place in the pantheon of heroes of the victory over the Red Army.

There is also the question as to whether this place was awarded to women associated in the Volunteer Women's Legion [Ochotnicza Legia Kobiet] established in 1918, who first took an active part in the Battle of Lviv during the Polish-Ukrainian war and in the Polish-Soviet War, including the battles for Vilnius and in the Battle of Warsaw. Does any of the threads fully reflect the involvement of volunteers who worked not only in the sanitary service but were also in the infantry, cavalry, artillery, supplies and intelligence? The authors of film studies claim that both films clearly reflect the involvement of women, presenting the protagonists as nurses and discussing the subject of enlisting women into active military service. Film expert, Lubelski, draws attention, for example, to the figure of Hanka in For You, o Poland, who "as a result of an oath taken... twice joins the warfare: first as a nurse, then - when the enemy becomes more and more dangerous - cutting her hair and changing her uniform as a soldier. Then she meets her beloved, Franek, and they both pray in front of the Gate of Dawn [Ostra Brama] in Vilnius". 48

Here it should be clarified that Hanka - or any other female character in For You, o Poland - does not have the honour of fighting with weapons. Moreover, her willingness to participate in defence of her homeland is not only for patriotic reasons. As the caption informs, Hanka decides to become a nurse because she also wants to "serve the Motherland". However, she goes to the front motivated above all by her love for Franek: "Wishing to be as close to her beloved as possible, Hanka went to one of the hospitals near Vilnius". Hanka

${ }^{47}$ See the article by Christhardt Henschel in the present volume.

${ }^{48}$ Lubelski, Historia kina polskiego. 
remains in the hospital while the action takes place in impressive battle scenes where infantry and tanks head to Vilnius to take on the enemy. The background music, which emphasises the horror of the epic-scale dramatic battles for Vilnius, is also used for scenes in which Hanka matures to the decision to join the army. Equally long and moving scenes emphasise the drama of Hanka, who says goodbye to her femininity, cuts her hair, puts on a uniform to finally go to the front. Dressed up as a man, she nevertheless shows the lack of orientation attributed to women. She is looking for the right path, which is shown to her by the soldier she has just met. Having lost a lot of time, unfortunately, she arrives too late, according to the caption: "Hanka's plans did not come to fruition. The conquest of Vilnius did not allow her to join the ranks of the fighters any more". By going to the Gate of Dawn, a place of Marian cult and a symbol of Polishness in multicultural Vilnius, Hanka happily achieves her main goal. Kneeling in front of the miraculous painting of Holy Mother, she recognises her beloved Franek from among those praying. Later, saluting in a soldierly way in front of a familiar chieftain, she reports on the completed task: "Sir, I dutifully report that I have found my Franek...".

Similarly, we do not see female soldiers in any of the battle scenes in Miracle on the Vistula. Krysta, who is interested in the military in the field of plastic arts by sculpting a soldier figure, remains at the manor. Although the laboratory technician Ewa sets out to the area of hostilities, she - like Hanka in For You, o Poland - is primarily driven by the love of her intended. The following caption so informs: "Ewa also put on a soldier's uniform to be closer to her beloved doctor Powada, who is now helping wounded soldiers in one of the field hospitals".

It transpires that the women in both films only play subordinate roles and are not on an equal footing with men as the fully-fledged participants in the victory over the Bolsheviks. Female patriotism is basically different and subject to male commitment to defend the homeland. A woman may operate in the area designated by the motif of a Polish mother, represented in Miracle on the Vistula by Mrs Granowska, or in the auxiliary function as a nurse. The actual warriors, the revered combatants of the Polish-Soviet War, are Catholic men like Franek and Jerzy.

According to the Miracle on the Vistula, a particular place in the pantheon of national heroes is given to the priest Ignacy Skorupka. The clergyman who died during the Battle of Warsaw while administering 
the last rites to one of the soldiers was venerated as a fighter and martyr, and his death was used to emphasise the religious nature of the struggle against the Bolsheviks as military action in the name of Christ. ${ }^{49}$ Contrary to the facts, but according to the created legend, the film portrays Father Skorupka with a cross in his hand, leading the soldiers to the attack. He dies on the spot hit by an enemy bullet, which in a transcendental way gives strength to the Polish infantry and cavalry units that thwart the Bolsheviks. Thanks to the same intervention from Heaven, Dr Jan Powada and his beloved Ewa are not shot by the Bolsheviks. As a gesture of thanks, Ewa makes the sign of the cross.

The world, turned upside down by the Bolsheviks and communist ideology, is restored to order in the endings of both films. In For You, $o$ Poland, these are scenes from the harvest festival held in Okrzyniec in August 1919, which evoke surrender relations from the feudal period. Peasants come to Marcin Oksza, who is standing on the stairs with his hands in his pockets, and announce, according to the caption: "We have brought the harvest, master. The first harvest in our free, reborn Poland". Stressing the acceptance of unequal relations, one of the peasants approaches the lord of the manor and squeezes him by the legs. The grateful nobleman replies, "Thank you, dear ones, thank you. May God continue to come to our aid".

The plot in Miracle on the Vistula ends with the double wedding of Jerzy and Krysta and doctor Powada and Ewa, referring to the issue of a wasted chance for independence raised in Wyspiański's drama. The double wedding, at which representatives of two states enjoy merriment, represents the joy felt at re-defended sovereignty of the Polish state. The film features material culture, rich folk costumes with corsets and wreaths, as well as folk dances.

\section{IV}

THE RECEPTION OF FOR YOU, O POLAND AND MIRACLE ON THE VISTULA BASED ON THE EXAMPLE OF WARSAW

The national community imagined in both films refers essentially to the idea of establishing Poland as a national Catholic and ethnically homogeneous country. By proposing a social model that is contrary to the idea of communism, this community accepts and integrates social

${ }^{49}$ Ratajczakowa, 'Cud nad Wista', 123-36. 


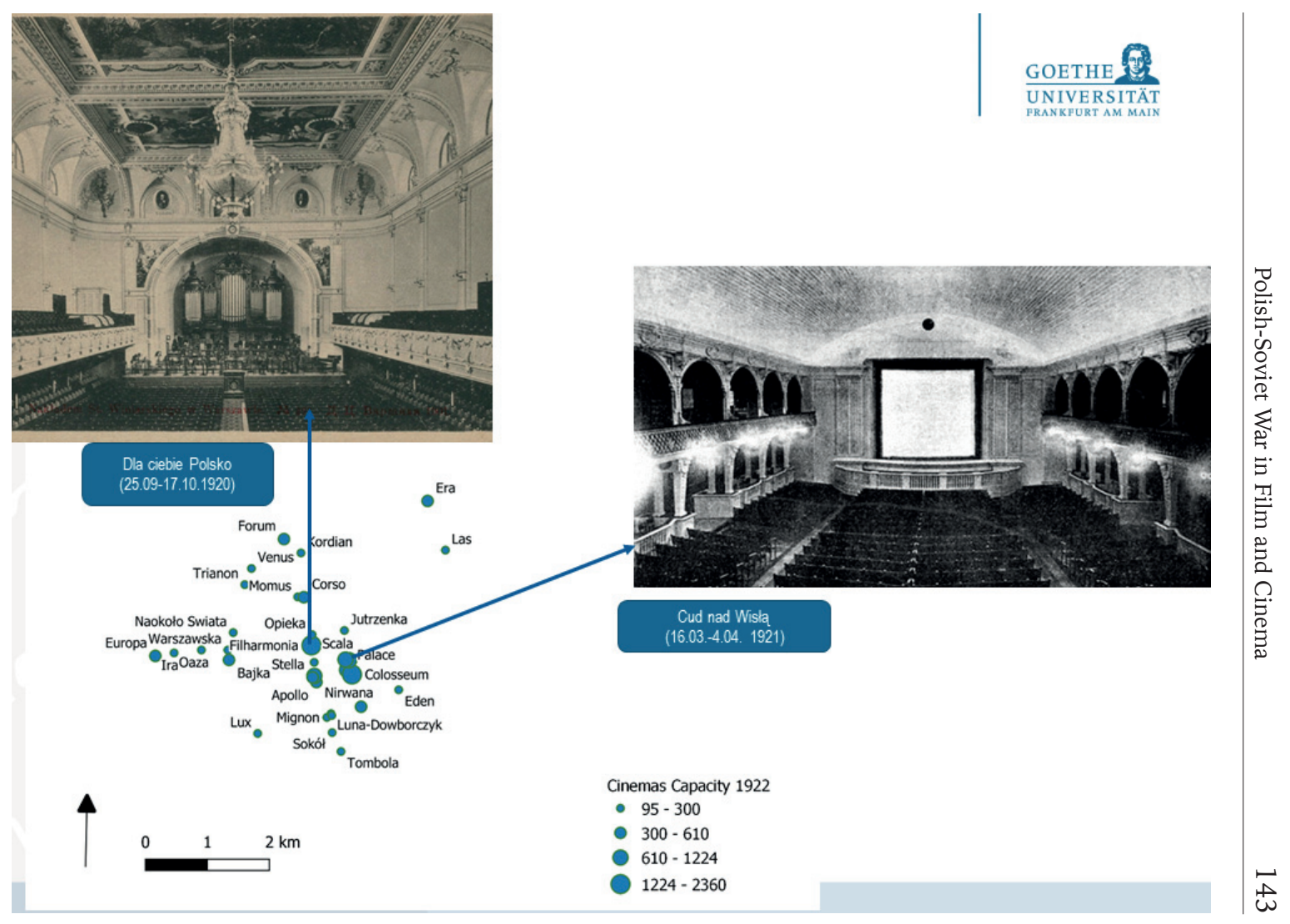


inequalities, discrimination against women and a rejection of national minorities. However, a great research challenge is the analysis of the historical reception of both films due to the scarcity of the source base.

The first conclusions were drawn based on data mining of articles and reviews published in local newspapers in Polish and Yiddish and spatial analysis using the QGIS program. The latter allowed for an outlining of the profile of the audience of the Philharmonic cinema, which screened For You, o Poland and in the Palace Cinema, where Miracle on the Vistula had been shown. From the map below and the standard of cinemas, it can be concluded that both high-end cinemas located in the city centre, offering high comfort and excellent musical accompaniment, generally attracted wealthier Warsaw residents.

As the local press reported, the audience for these projections was additionally enlarged. Taking advantage of the tax breaks, the directors of these cinemas offered discounts for soldiers and youth and organised special screenings for school classes. At the current research stage, little can be said about the presence of women in the screenings of the films in question.

However, it can be assumed that the shows were attended not only by the Christian population but also by Jews, who in the discussed period constituted approximately 33 per cent of the total population of Warsaw. ${ }^{50}$ This assumption is confirmed by the map below, which visualises the topography of cinemas and the density of the Jewish population in individual districts. It shows that only a few cinemas had audiences that were not very diverse in terms of nationality, religion and culture. Most cinemas, and this certainly applies to premiere cinemas, such as the Philharmonic and the Palace, located in the city centre, attracted cinema fans of both religious groups.

The known marketing strategies of cinemas also confirm this assumption. The managers of both cinemas, who knew the local film market, placed advertisements in the Polish press as well as in the Jewish press published in Polish and Yiddish. For example, Miracle on the Vistula was announced in the daily Haynt translated into Yiddish as Der nes baym vaykhsel. Szymon Lejman, the owner of the Stella cinema on Marszałkowska Street, who showed Miracle on the Vistula in April 1921, also targeted the readers of this daily. ${ }^{51}$

${ }^{50}$ N.N., 'Ludność: Rozwój ludności 1792-1939', Warszawa w liczbach (1947), 3.

51 'Stella Cud nad Wisłą', Kurier Poranny (27 April 1921). 


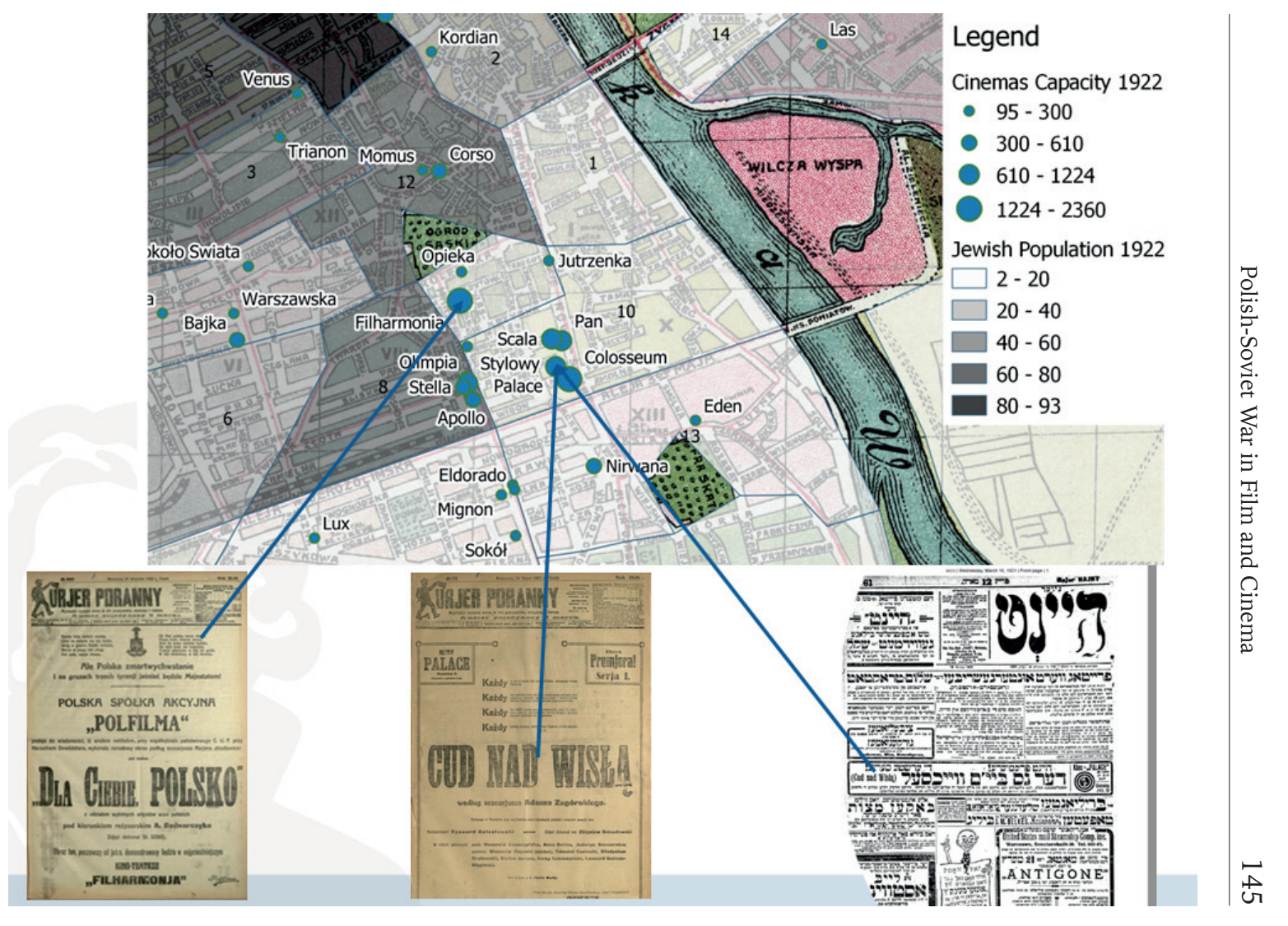


However, local Polish dailies, which also published short favourable reviews, posted the largest number of announcements. As the description in Kurier Warszawski shows, For You, o Poland aroused patriotic emotions: "The audience followed the course of this action with great interest, enthusiastically applauding the heroic deeds of our army. Warm applause could also be heard when Vilnius appeared on the screen. Viewers cried out: long live Vilnius. In general, the picture made an indelible impression". ${ }^{52}$ Kurier Poranny similarly advertised Miracle on the Vistula as an excellent film spectacle, ${ }^{53}$ and Gazeta Poranna 2 Grosze wrote about the successful presentation of the struggles of "the army and the entire nation with the onslaught of Bolshevism, which had already reached the heart of Poland". ${ }^{54}$

The omission of Jewish volunteers and the declassification of the participation of women in the national fighting community as a whole was not, however, the subject of criticism. Unfortunately, the search conducted with the use of full-text search engines in local newspapers in Polish and Yiddish did not bring any results in this respect. Therefore, it is difficult to establish how these exclusion mechanisms affected attendance. Basically, it can be concluded that both films, with their four- and three-week runs in the Philharmonic and Palace respectively, enjoyed decent but not spectacular commercial success. The more box office films did not leave the premiere cinemas for months.

The reasons for the emergence of these differences may be the subject of separate studies of cinema programs and the popularity of films, which have not yet been undertaken in Polish film studies in relation to the analysed period. Thus, new exploration possibilities are opening up for the researchers concerned. Closer cooperation between disciplines, broadening the source base, and crossing perspectives would allow for confronting the reality created in Polish film productions with the national, cultural, linguistic diversity and division into gender, which characterised the communicative community of Polish cinematography prior to the conflagration of the Second World War.

\section{transl. Barry Keane}

52 'Dla ciebie Polsko', Kurier Warszawski (20 Oct. 1920).

53 'Stella Cud nad Wisłą', Kurier Poranny (27 April 1921).

54 'Kronika. Cud nad Wisłą', Gazeta Poranna 2 Grosze (12 March 1921). 


\section{SELECTED BIBLIOGRAPHY}

Anderson Benedict Richard O'Gorman, Imagined Communities: Reflections on the Origin and Spread of Nationalism (London, 1991).

Bauer Ela, 'The Jews and the Silver Screen: Poland at the End of the 1920s', Journal of Modern Jewish Studies, xvi, 1 (2017), 80-99.

Białous Maciej, Spoleczna konstrukcja filmów historycznych. Pamięć zbiorowa i polityka pamięci w kinematografii polskiej lat 1920-2010 (Białystok, 2015).

Deutsch Karl Wolfgang, Nationalism and Social Communication. An Inquiry into the Foundations of Nationality (Cambridge, MA, 1966).

Gross Natan, Film żydowski w Polsce (Kraków, 2002).

Guzek Mariusz and Zwierzchowski Piotr (eds), 1918 - kino polskie wobec odzyskania niepodlegtości (Bydgoszcz, 2020).

Hendrykowska Małgorzata, Historia polskiego filmu dokumentalnego (1896-1944) (Poznań, 2014).

Klenotic Jeffrey, 'Putting Cinema History on the Map: Using GIS to Explore the Spatiality of Cinema', in Richard Maltby, Daniël Biltereyst, and Philippe Meers (eds), Explorations in New Cinema History: Approaches and Case Studies (Malden MA, 2011), 58-84.

Lubelski Tadeusz and Stroiński Maciej (eds), Kino polskie jako kino narodowe (Kraków, 2009).

Lubelski Tadeusz, Historia kina polskiego: Twórcy, filmy, konteksty (Katowice, 2009).

Piotrowska Monika, 'Rola i znaczenie filmu w popularyzacji historii a kształtowanie społecznej świadomości historycznej', Zeszyty Naukowe Towarzystwa Doktorantów UJ Nauki Humanistyczne, 14 (2016), 59-78.

Pogonowska Ewa, Dzikie biesy: Wizja Rosji sowieckiej w antybolszewickiej poezji polskiej lat 1917-1932 (Lublin, 2002).

Pufelska Agnieszka, 'Stabile Feindbilder gegen die instabile Zeit Der jüdische Bolschewismus als Propagandainstrument in der Weimarer Republik', in Jörg Ganzenmüller, Gerd Koenen, Bernhard H. Bayerlein, Eva Oberloskamp, Karsten Brüggemann, Agnieszka Pufelska, Thomas Kroll, Hans Woller, and Julia Richers (eds), Verheißung und Bedrohung: Die Oktoberrevolution als globales Ereignis (Göttingen, 2019).

Ratajczakowa Dobrochna, 'Cud nad Wista. Obrazy wojny polsko-sowieckiej 1920 roku w dramacie popularnym lat dwudziestych', Roczniki Humanistyczne, xlii, 1 (1994), 123-36.

Witek Piotr, 'Metafora źródła czyli film w funkcji poznawczej', Przegląd Humanistyczny, xlvi, 1 (2002), 57-70.

Karina Pryt - economic and social history of cinema, visual culture, film policy of the national socialists; post-doc research fellow at the Institute for Theatre, Film and Media Studies at the Goethe University in Frankfurt am Main;

e-mail:Pryt@tfm.uni-frankfurt.de 